\title{
Grain Size and Heavy Minerals Analysis of Maastrichtian Sandstone, Anambra Basin, Nigeria: Implication for Aquifer Properties
}

\author{
*ILEVBARE, M; IMASUEN, OI
}

\author{
Department of Geology, University of Benin, Benin City, Nigeria. \\ ${ }^{*}$ Corresponding Author Email: ilevbaremartins777@gmail.com; Tel: +234 8036993220
}

\begin{abstract}
The Maastrichtian sediments of Anambra Basin, south western Nigeria was studied for grain characteristics and maturity of the sediments, so that by combining sedimentological characteristics, maturity and its paleoenvironment of deposition of the Ajali sandstone, in order to ascertain the aquifer properties of the groundwater within the study area and by extension the availability of drinking water for both the urban and rural settlers. Grain size analysis (51 samples) and heavy mineral analysis (15 samples each) were analyzed. The textural parameters show that the Sandstone are medium sand, poorly to moderately sorted, coarse to strongly coarse skewed with mesokurtic to leptokurtic grains. The heavy minerals present in lithologic sand and sandstone units of Ajali Formation are mainly zircon, rutile, tourmaline, apatite, staurolite, and opaque minerals (Goethite, hematite, ilmenite), these heavy minerals found in the sandstone are associated with igneous and metamorphic source which indicates that these maastritchian sediments are from basement complex rock The ZTR index of $67.96 \%$ and the values of the kurtosis indicates a sub-mature sandstone to mature sandstone, which gives an excellent aquifer properties. Also, the paleoenvironment of deposition of the Maastrichtian sediments is Fluvial. The sand and sandstone bodies deposited in a fluvial system have sheet-like geometries and due to the differences in the extent of aquifer compartmentalization, Sandstone deposited in fluvial environment normally has better hydraulic conductivity which again reveals a good aquifer property. The sedimentological characteristics for the Sandstone exposed at Fugar and environs, is a coarsening upward sequence (increasing grain sizes) with a progressive increase in sorting. since hydraulic conductivity increases with increasing grain sizes and sorting, hence, excellent aquifer characteristics for the groundwater within the study area. The foregoing revealed that the aquifer geometry and properties of the study areas is favourable for the availability of drinking water for both the Urban and rural dwellers within these communities.
\end{abstract}

DOI: https://dx.doi.org/10.4314/jasem.v24i11.7

Copyright: Copyright $(\subset) 2020$ Ilevbare and Imasuen. This is an open access article distributed under the Creative Commons Attribution License (CCL), which permits unrestricted use, distribution, and reproduction in any medium, provided the original work is properly cited.

Dates: Received: 20 September 2020; Revised: 29 October 2020; Accepted: 10 November 2020

Keywords: Aquifer geometry, groundwater, hydraulic conductivity, Anambra Basin.

The Maastrichtian siliciclastic sedimentary units of the Ajali Formation, (Anambra Basin) is an extensive stratigraphic unit conformably overlying the Lower coal measure (Mamu Formation) and underlying the Upper coal measure (Nsukka Formation) in the Maastrichtian. The environment of deposition has been discussed by various authors especially Simpson (1954), Reyment (1965), Hoque and Ezepue (1977) and Ladipo (1986). Simpson (1954), in the Nigerian Geological Survey report described the lithostratigraphic unit as False bedded Sandstone. Reyment (1965), associating it with its type locality, formally named it False bedded Sandstone. Sandstone is the principal terrigenous clastic aquifer lithology, due to its high initial porosity and permeability i.e. hydraulic conductivity, (Hiatt and Kyser, 2014). The grain size of sediment depends largely on the character of the source rocks, weathering processes, abrasion and selective sorting during transportation. Sediment particles are segregated according to their hydrodynamic behaviour and depend mainly on the particle size. Mean grain size is a reflection of the competency of the transporting system (Ramasamy and Karikalan, 2010; Marshall, 1967). Depositional processes control initial porosity and permeability relationships in basin-filling sedimentary successions. These initial conditions then determine how diagenesis modifies the hydraulic properties of sediments as they undergo burial and lithification. Therefore, combining sedimentology, stratigraphy and diagenesis to understand the paleohydrologic evolution of sedimentary rocks throughout the evolution of basins is a necessary part of "basin analysis" (Hiatt and Kyser, 2014). Diagenesis can result in complete inversion of original aquifer characteristics. Lithologies that initially had excellent aquifer properties, such as high intergranular porosity and high hydraulic conductivity permeability) can, through compaction and cementation during evolution of the Basin, become aquitards. Conversely, facies that were initially poor aquifers can, through diagenetic 
modification, become conduits through which important diagenetic fluids flow, especially in deep portions of the basin. Therefore, understanding diagenetic processes and their timing is critical for developing hydrologic models, (Hiatt and Kyser, 2014).

This study was initiated to evaluate the grain characteristics and maturity of the sediments in view of its hydraulic conductivity and aquifer geometry and its influence on groundwater availability and aquifer properties of the locality. The study provides resourceful knowledge to the groundwater system in the area, which facilitates policy making on environmental management plans, groundwater quality, protection and management within the study area and by extension the world.

\section{MATERIALS AND METHOD}

Sample Collection: The study area and its environs are situated in Fugar, Ayogwuiri, Auchi and Uzebba all within the Ajali Formation. The area is highly accessible with major and minor roads, together with other adjoining roads. The location map of the study area, (figures 1) was generated using the GPS coordinates obtained from the field studies. Samples were collected at an interval of $0.6 \mathrm{~m}$ in 5 different locations within the study area. In all, 51 samples were collected from the 5- locations and analyzed for grain size analysis and 15 samples (3 from each sampled location) for heavy minerals analysis and the procedures are detailed below.

Grain Size Analysis: $50 \mathrm{~g}$ was weighed from each sample and mechanically sieved at the Sedimentology laboratory in the Department of Geology, University of Benin, Nigeria. Median, mean, sorting, skewness and kurtosis were thereafter computed from the recorded weight percentages of the sieves and pan.

Heavy Mineral Analysis: 25 samples each (5 samples per location) were selected for heavy mineral analyses. The experimental procedure entailed pouring $5 \mathrm{~g}$ of air-dried sample into an already mounted separating funnel filled to $3 / 4$ of its volume with bromoform. The heavy minerals contained in the samples which sunk to the bottom of the funnel was collected in a filter paper, washed with acetone to remove all the bromoform, and mounted afterwards on a clean glass slide using DPX mountant. Mineral identification and textural analysis, point counting of mineral grains were carried out on the slides using a transmitted light microscope at the Sedimentology laboratory in the Department of Geology, University of Benin.

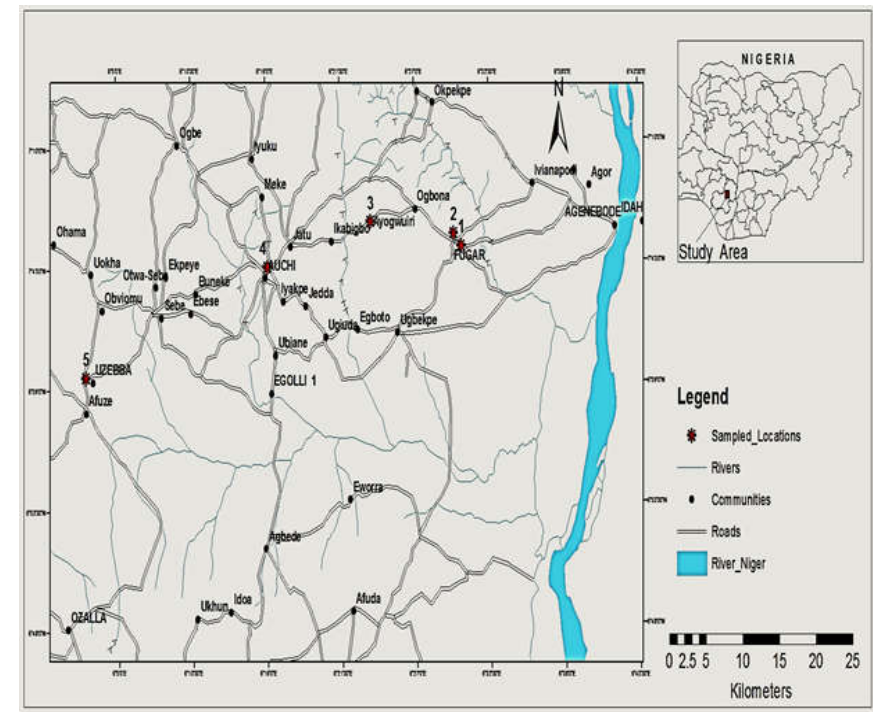

Fig 1: Location map of Study area

\section{RESULTS AND DISCUSSION}

The results of the Grain sizes and Heavy mineral analyses are presented (Tables 1, 2, 3 and 4) and figure 2 together with some photomicrograph of heavy minerals analyzed. Medium sand with moderately sorted grains and a vast majority of the moderately sorted grains are negatively skewed, $35.3 \%$ are coarse skewed, $29.4 \%$ are fine skewed, and $17.6 \%$ strongly coarse skewed, $11.8 \%$ near symmetry and only $5.9 \%$ strongly fine skewed. The sediments are $47.1 \%$ mesokurtic, $23.5 \%$ leptokurtic, $11.8 \%$ each of platykurtic and very leptokurtic and 5.9\% extremely leptokurtic. Sediments are mainly mesokurtic and leptokurtic. 
Table 1: Textural Parameters of Sandstone at Fugar

\begin{tabular}{|c|c|c|c|c|c|c|}
\hline \multirow{2}{*}{$\begin{array}{l}\text { Sample } \\
\text { ID }\end{array}$} & \multicolumn{5}{|c|}{ Grain Size Parameters } & \multirow[t]{2}{*}{ Description } \\
\hline & $\begin{array}{l}\text { Median } \\
\phi\end{array}$ & $\begin{array}{l}\text { Mean } \\
\phi\end{array}$ & $\begin{array}{l}\text { Std. } \\
\text { deviation } \phi\end{array}$ & $\begin{array}{l}\text { Skewness } \\
\phi\end{array}$ & $\begin{array}{l}\text { Kurtosis } \\
\phi\end{array}$ & \\
\hline $\mathrm{A}_{1}$ & 1.70 & 1.63 & 0.79 & -0.14 & 0.97 & $\begin{array}{l}\text { Medium sand, Moderately Sorted, Coarse Skewed } \\
\text { and Mesokurtic. }\end{array}$ \\
\hline $\mathrm{A}_{2}$ & 1.70 & 1.60 & 0.86 & -0.22 & 1.08 & $\begin{array}{l}\text { Medium sand, Moderately Sorted, Coarse Skewed } \\
\text { and Mesokurtic }\end{array}$ \\
\hline $\mathrm{A}_{3}$ & 1.70 & 1.50 & 0.95 & -0.48 & 1.13 & $\begin{array}{l}\text { Medium sand, Moderately Sorted, Strongly fined } \\
\text { skewed and Leptokurtic }\end{array}$ \\
\hline $\mathrm{A}_{4}$ & 1.80 & 1.70 & 0.64 & -0.30 & 1.64 & $\begin{array}{l}\text { Medium sand, Moderately well Sorted, Coarse } \\
\text { Skewed and Very Leptokurtic }\end{array}$ \\
\hline $\mathrm{A}_{5}$ & 0.80 & 0.70 & 0.46 & -0.13 & 0.80 & $\begin{array}{l}\text { Coarse sand, Well Sorted, Coarse Skewed and } \\
\text { Platykurtic }\end{array}$ \\
\hline $\mathrm{A}_{6}$ & 0.20 & 0.30 & 1.50 & 0.03 & 0.94 & $\begin{array}{l}\text { Coarse sand, Poorly Sorted, Strongly Coarse Skewed } \\
\text { and Mesokurtic }\end{array}$ \\
\hline $\mathrm{A}_{7}$ & 1.10 & 1.79 & 0.82 & 0.17 & 1.04 & $\begin{array}{l}\text { Medium sand, Moderately sorted, Fine Skewed and } \\
\text { Mesokurtic }\end{array}$ \\
\hline $\mathrm{A}_{8}$ & 0.50 & 0.73 & 0.78 & 0.46 & 0.97 & $\begin{array}{l}\text { Coarse sand, Moderately Sorted, Fine Skewed and } \\
\text { Mesokurtic }\end{array}$ \\
\hline $\mathrm{A}_{9}$ & 0.80 & 0.87 & 0.71 & 0.18 & 1.11 & $\begin{array}{l}\text { Coarse sand, Moderately Sorted, Near Symmetrical } \\
\text { and Leptokurtic }\end{array}$ \\
\hline $\mathrm{A}_{10}$ & 1.00 & 1.07 & 0.66 & 0.17 & 0.82 & $\begin{array}{l}\text { Medium sand, Moderately well Sorted, Fine Skewed } \\
\text { and Platykurtic }\end{array}$ \\
\hline $\mathrm{A}_{11}$ & 0.90 & 0.90 & 0.39 & 0.06 & 3.28 & $\begin{array}{l}\text { Coarse sand, Well Sorted, Strongly Coarse Skewed } \\
\text { and Extremely Leptokurtic }\end{array}$ \\
\hline $\mathrm{A}_{12}$ & 1.00 & 1.17 & 0.55 & 0.53 & 1.80 & $\begin{array}{l}\text { Medium sand, Moderately well Sorted, Fine Skewed } \\
\text { and Very Leptokurtic }\end{array}$ \\
\hline $\mathrm{A}_{13}$ & 1.40 & 1.27 & 0.79 & -0.26 & 1.49 & $\begin{array}{l}\text { Medium sand, Moderately Sorted, Coarse Skewed } \\
\text { and Leptokurtic }\end{array}$ \\
\hline $\mathrm{A}_{14}$ & 1.50 & 1.53 & 0.73 & 0.02 & 1.38 & $\begin{array}{l}\text { Medium sand, Moderately Sorted, Strongly Coarse } \\
\text { Skewed and Mesokurtic }\end{array}$ \\
\hline $\mathrm{A}_{15}$ & 1.50 & 1.33 & 1.04 & -0.30 & 1.07 & $\begin{array}{l}\text { Medium sand, Moderately Sorted, Coarse Skewed } \\
\text { and Mesokurtic }\end{array}$ \\
\hline $\mathrm{A}_{16}$ & 1.00 & 1.00 & 0.76 & 0.11 & 1.11 & $\begin{array}{l}\text { Coarse sand, Moderately Sorted, Near Symmetrical } \\
\text { and Mesokurtic }\end{array}$ \\
\hline $\mathrm{A}_{17}$ & 1.10 & 1.10 & 0.84 & 0.10 & 1.19 & $\begin{array}{l}\text { Medium sand, Moderately Sorted, Fine Skewed and } \\
\text { Leptokurtic }\end{array}$ \\
\hline
\end{tabular}

Table 2: Textural Parameters of Sandstone at Fugar II

\begin{tabular}{|c|c|c|c|c|c|c|}
\hline \multirow{2}{*}{$\begin{array}{l}\text { Sample } \\
\text { ID }\end{array}$} & \multicolumn{5}{|c|}{ Grain Size Parameters } & \multirow[t]{2}{*}{ Description } \\
\hline & $\begin{array}{l}\text { Median } \\
\phi\end{array}$ & $\begin{array}{l}\text { Mean } \\
\phi\end{array}$ & $\begin{array}{l}\text { Std. } \\
\text { deviation } \phi\end{array}$ & $\begin{array}{l}\text { Skewness } \\
\phi\end{array}$ & $\begin{array}{l}\text { Kurtosis } \\
\phi\end{array}$ & \\
\hline $\mathrm{B}_{1}$ & 1.60 & 1.53 & 0.68 & -0.14 & 0.94 & $\begin{array}{l}\text { Medium sand, Moderately well Sorted, Coarse Skewed } \\
\text { and Mesokurtic }\end{array}$ \\
\hline $\mathrm{B}_{2}$ & 1.70 & 1.70 & 0.67 & -0.08 & 1.40 & $\begin{array}{l}\text { Medium sand, Moderately well Sorted, Near } \\
\text { Symmetrical and Mesokurtic }\end{array}$ \\
\hline $\mathrm{B}_{3}$ & 1.50 & 1.27 & 0.64 & -0.13 & 1.41 & $\begin{array}{l}\text { Medium sand, Moderately well Sorted, Coarse skewed } \\
\text { and Mesokurtic }\end{array}$ \\
\hline $\mathrm{B}_{4}$ & 1.50 & 1.57 & 0.57 & 0.19 & 0.81 & $\begin{array}{l}\text { Medium sand, Moderately well Sorted, Near } \\
\text { Symmetrical and Platykurtic }\end{array}$ \\
\hline $\mathrm{B}_{5}$ & 1.70 & 1.63 & 0.60 & -0.18 & 0.91 & $\begin{array}{l}\text { Medium sand, Moderately Well Sorted, Coarse Skewed } \\
\text { and Mesokurtic }\end{array}$ \\
\hline $\mathrm{B}_{6}$ & 1.20 & 1.17 & 0.81 & -0.08 & 1.32 & $\begin{array}{l}\text { Medium sand, Moderately Sorted, Near Symmetrical and } \\
\text { Leptokurtic }\end{array}$ \\
\hline $\mathrm{B}_{7}$ & 1.30 & 1.30 & 0.62 & 0.071 & 1.08 & $\begin{array}{l}\text { Medium sand, Moderately well Sorted, Strongly Coarse } \\
\text { Skewed and Mesokurtic }\end{array}$ \\
\hline $\mathrm{B}_{8}$ & 1.50 & 1.50 & 0.55 & -0.05 & 1.17 & $\begin{array}{l}\text { Medium sand, Moderately well Sorted, Near } \\
\text { Symmetrical and Leptokurtic }\end{array}$ \\
\hline $\mathrm{B}_{9}$ & 1.70 & 1.63 & 0.59 & -0.12 & 0.97 & $\begin{array}{l}\text { Medium sand, Moderately well Sorted, Coarse Skewed } \\
\text { and Mesokurtic }\end{array}$ \\
\hline $\mathrm{B}_{10}$ & 0.80 & 0.70 & 0.59 & -0.02 & 1.23 & $\begin{array}{l}\text { Coarse sand, Moderately well Sorted, Near Symmetrical } \\
\text { and Leptokurtic }\end{array}$ \\
\hline $\mathrm{B}_{11}$ & 1.90 & 2.00 & 0.50 & 0.17 & 1.50 & $\begin{array}{l}\text { Fine sand, Moderately well Sorted, Near Symmetrical } \\
\text { and Leptokurtic }\end{array}$ \\
\hline $\mathrm{B}_{12}$ & 1.00 & 0.90 & 0.79 & 0.17 & 1.15 & $\begin{array}{l}\text { Coarse sand, Moderately Sorted, Near Symmetrical and } \\
\text { Leptokurtic }\end{array}$ \\
\hline
\end{tabular}


Table 3: Textural Parameters of Sandstone at Ayogwuiri

\begin{tabular}{|c|c|c|c|c|c|c|}
\hline \multirow{2}{*}{$\begin{array}{l}\text { Sample } \\
\text { ID }\end{array}$} & \multicolumn{5}{|c|}{ Grain Size Parameters } & \multirow[t]{2}{*}{ Description } \\
\hline & $\begin{array}{l}\text { Median } \\
\phi\end{array}$ & $\begin{array}{l}\text { Mean } \\
\phi\end{array}$ & $\begin{array}{l}\text { Std. } \\
\text { deviation } \phi\end{array}$ & $\begin{array}{l}\text { Skewness } \\
\phi\end{array}$ & Kurtosis $\phi$ & \\
\hline $\mathrm{C}_{1}$ & 1.30 & 1.30 & 1.02 & -0.03 & 1.07 & $\begin{array}{l}\text { Medium sand, Poorly Sorted, Near Symmetrical } \\
\text { and Mesokurtic }\end{array}$ \\
\hline $\mathrm{C}_{2}$ & 1.50 & 1.40 & 0.95 & -0.13 & 1.23 & $\begin{array}{l}\text { Medium sand, Moderately Sorted, Coarse Skewed } \\
\text { and Leptokurtic }\end{array}$ \\
\hline $\mathrm{C}_{3}$ & 1.60 & 1.53 & 1.05 & -0.11 & 1.22 & $\begin{array}{l}\text { Medium sand, Moderately well Sorted, Coarse } \\
\text { skewed and Leptokurtic }\end{array}$ \\
\hline $\mathrm{C}_{4}$ & 1.30 & 1.30 & 1.10 & -0.11 & 0.98 & $\begin{array}{l}\text { Medium sand, Poorly Sorted, Coarse Skewed and } \\
\text { Mesokurtic }\end{array}$ \\
\hline $\mathrm{C}_{5}$ & 1.20 & 1.27 & 0.98 & 0.08 & 1.01 & $\begin{array}{l}\text { Medium sand, Moderately Sorted, Near } \\
\text { Symmetrical and Mesokurtic }\end{array}$ \\
\hline $\mathrm{C}_{6}$ & 1.40 & 1.37 & 1.18 & -0.07 & 1.03 & $\begin{array}{l}\text { Medium sand, Poorly Sorted, Near Symmetrical } \\
\text { and Mesokurtic }\end{array}$ \\
\hline $\mathrm{C}_{7}$ & 0.30 & 0.40 & 0.87 & 0.25 & 0.96 & $\begin{array}{l}\text { Coarse sand, Moderately Sorted, Fine Skewed and } \\
\text { Mesokurtic }\end{array}$ \\
\hline $\mathrm{C}_{8}$ & 1.30 & 1.30 & 1.04 & 0.05 & 0.10 & $\begin{array}{l}\text { Medium sand, Poorly Sorted, Strongly Coarse } \\
\text { Skewed and Mesokurtic }\end{array}$ \\
\hline $\mathrm{C}_{9}$ & 1.40 & 1.50 & 1.25 & 0.07 & 0.93 & $\begin{array}{l}\text { Medium sand, Poorly Sorted, Near Symmetrical } \\
\text { and Mesokurtic }\end{array}$ \\
\hline $\mathrm{C}_{10}$ & 1.30 & 1.23 & 1.19 & -0.11 & 0.99 & $\begin{array}{l}\text { Medium sand, Poorly Sorted, Coarse Skewed and } \\
\text { Mesokurtic }\end{array}$ \\
\hline
\end{tabular}

Table 4: Textural Parameters of Sandstone at Uzebba (D) and Auchi (E)

\begin{tabular}{|c|c|c|c|c|c|c|}
\hline \multirow{2}{*}{$\begin{array}{l}\text { Sample } \\
\text { ID }\end{array}$} & \multicolumn{5}{|c|}{ Grain Size Parameters } & \multirow[t]{2}{*}{ Description } \\
\hline & $\begin{array}{l}\text { Median } \\
\phi\end{array}$ & $\begin{array}{l}\text { Mean } \\
\phi\end{array}$ & $\begin{array}{l}\text { Std. } \\
\text { deviation } \phi\end{array}$ & $\begin{array}{l}\text { Skewness } \\
\phi\end{array}$ & Kurtosis $\phi$ & \\
\hline $\mathrm{D}_{1}$ & 2.30 & 2.30 & 0.30 & 0.14 & 1.43 & $\begin{array}{l}\text { Fine sand, Very well Sorted, Near Symmetrical and } \\
\text { Leptokurtic }\end{array}$ \\
\hline $\mathrm{D}_{2}$ & 2.30 & 2.13 & 0.75 & -0.39 & 1.03 & $\begin{array}{l}\text { Fine sand, Moderately Sorted, Strongly Coarse } \\
\text { Skewed and Mesokurtic }\end{array}$ \\
\hline $\mathrm{D}_{3}$ & 1.80 & 1.70 & 0.91 & -0.06 & 1.19 & $\begin{array}{l}\text { Medium sand, Moderately Sorted, Near } \\
\text { Symmetrical and Leptokurtic }\end{array}$ \\
\hline $\mathrm{D}_{4}$ & 2.20 & 2.13 & 0.66 & -0.25 & 1.64 & $\begin{array}{l}\text { Fine sand, Moderately well Sorted, Strongly Coarse } \\
\text { Skewed and Very Leptokurtic }\end{array}$ \\
\hline $\mathrm{D}_{5}$ & 2.30 & 2.30 & 0.68 & -0.81 & 1.46 & $\begin{array}{l}\text { Fine sand, Moderately well Sorted, Coarse Skewed } \\
\text { and Leptokurtic }\end{array}$ \\
\hline $\mathrm{E}_{1}$ & 1.80 & 1.80 & 0.69 & 0.02 & 0.94 & $\begin{array}{l}\text { Medium sand, Moderately well Sorted, Near } \\
\text { Symmetrical and Mesokurtic }\end{array}$ \\
\hline $\mathrm{E}_{2}$ & 2.30 & 2.30 & 0.87 & -0.07 & 1.04 & $\begin{array}{l}\text { Fine sand, Moderately Sorted, Near Symmetrical } \\
\text { and Mesokurtic }\end{array}$ \\
\hline $\mathrm{E}_{3}$ & 1.70 & 1.73 & 0.84 & 0.02 & 1.27 & $\begin{array}{l}\text { Medium sand, Moderately Sorted, Near } \\
\text { Symmetrical and Leptokurtic }\end{array}$ \\
\hline $\mathrm{E}_{4}$ & 1.40 & 1.43 & 0.77 & 0.07 & 0.97 & $\begin{array}{l}\text { Medium sand, Moderately Sorted, Near } \\
\text { Symmetrical and Mesokurtic }\end{array}$ \\
\hline $\mathrm{E}_{5}$ & 1.20 & 1.30 & 0.95 & 0.22 & 1.23 & $\begin{array}{l}\text { Medium sand, Moderately Sorted, Strongly Fine } \\
\text { Skewed and Mesokurtic }\end{array}$ \\
\hline $\mathrm{E}_{6}$ & 1.10 & 1.16 & 1.06 & 0.12 & 1.26 & $\begin{array}{l}\text { Medium sand, Poorly Sorted, Fine Skewed and } \\
\text { Leptokurtic }\end{array}$ \\
\hline $\mathrm{E}_{7}$ & 1.20 & 1.20 & 1.00 & 0.08 & 1.48 & $\begin{array}{l}\text { Medium sand, Moderately Sorted, Near } \\
\text { Symmetrical and Leptokurtic }\end{array}$ \\
\hline
\end{tabular}

D: Fine sand of moderate to well sorting. Strongly coarse skewed with leptokurtic to very leptokurtic grains. Predominantly negative skewed.

E: Medium sand, moderately to moderately well sorted, strongly coarse skewed, all been positively skewed except one, mesokurtic (57.1\%) to leptokuritic (42.9\%) grains. 

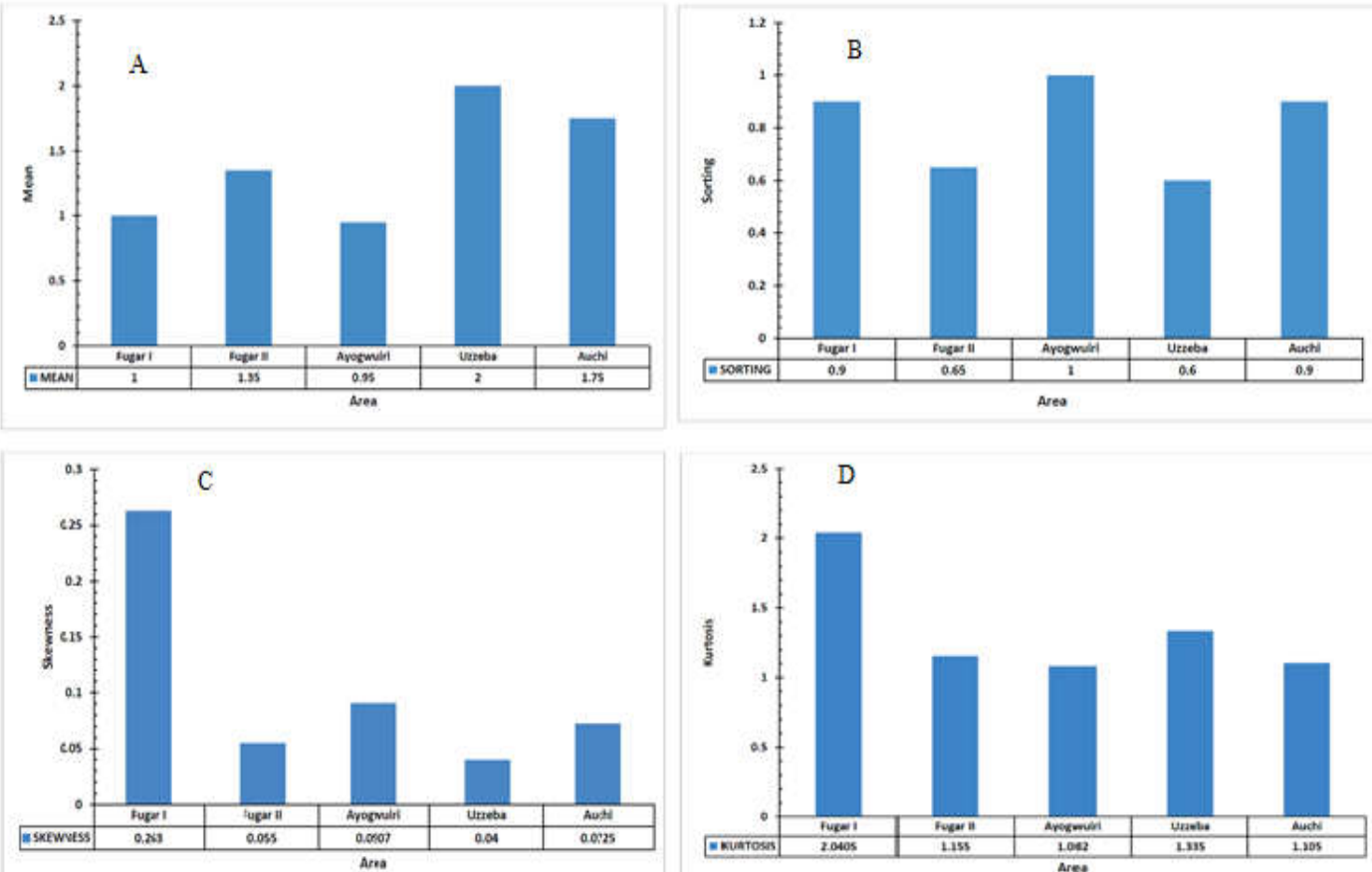

$A=$ The s andstone in Uzzeba and Avchi has highest graphic mean value while that of Fugar I Fugar II and Ayogwviri are approximately of the same range. B = From the chart, peak value of Sorting are seen in Ayogw viri, Avchi and Fug ar I S and stone is equally sorted, while sorting varies for Furgar II and Uzebba. C= The chart reveals extremely high skewness for Furg ar sandstones, with the least skeweness at Uzebba. $\mathrm{D}=$ Fugar I sandstone, equally shows extremely high Kurtosis with the Sand stone from Ayogwuiri having the least values.

Fig 2: (A) Mean (B) Sorting (C) Skewness and (D) Kurtosis against Study locations

Note: $A=$ Fugar, $B=$ Fugar II, $C=$ Ayogwuiri, and $D=$ Auchi $E=U z e b b a$

Table 5: Heavy minerals and Zircon Tourmaline Rutile (ZTR) index.

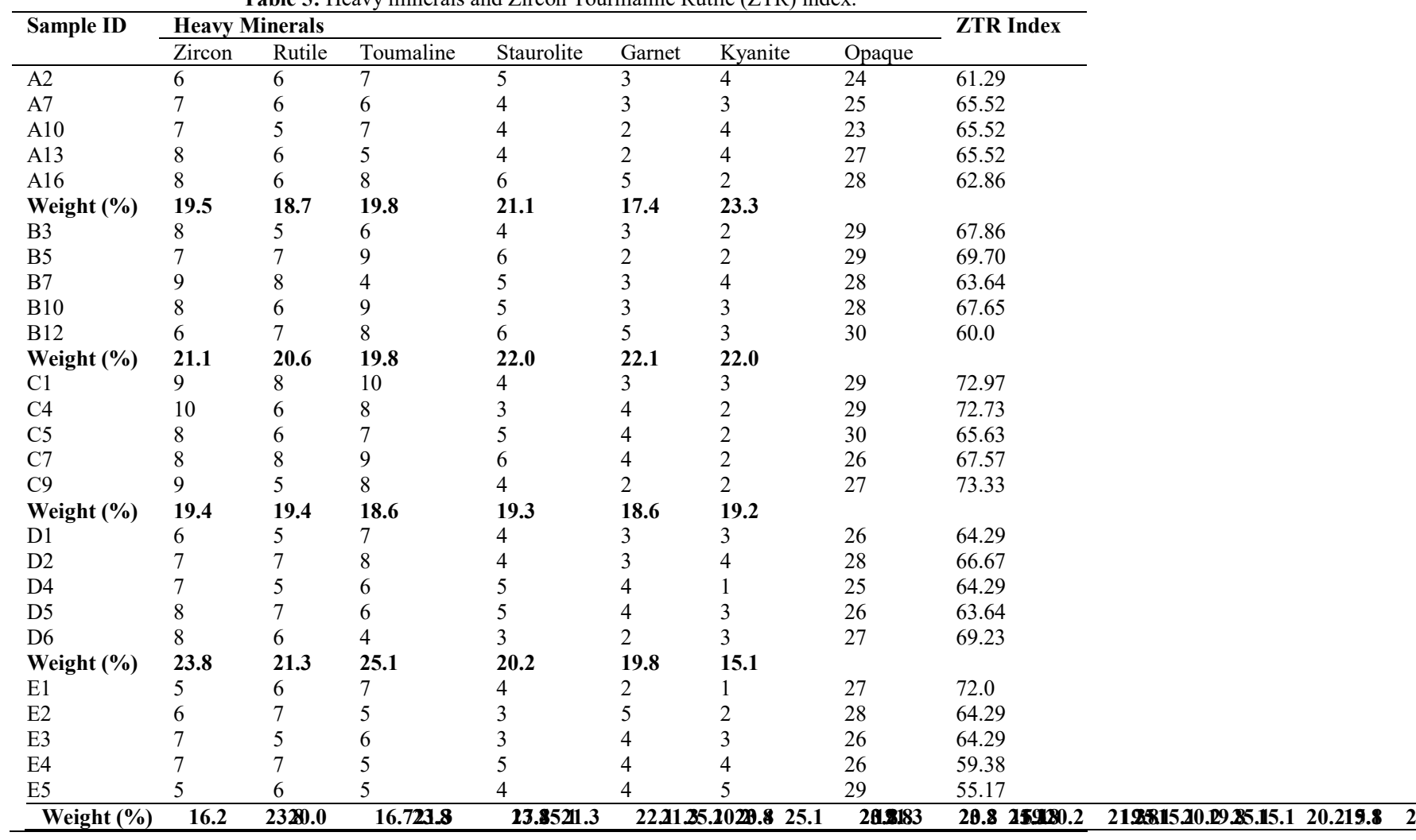



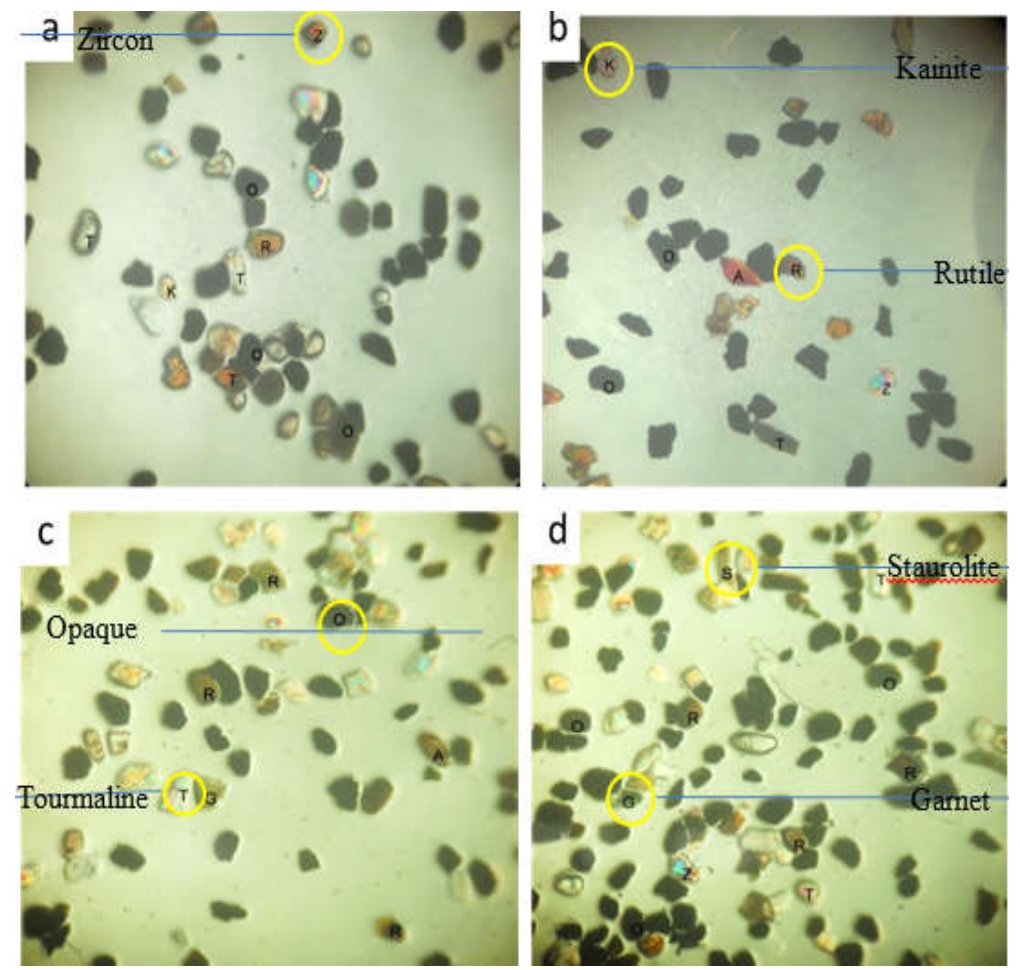

Fig 3: Photo micrograph of Heavy minerals analysis of Sandstone at Fugar, Ayowuiri, Auchi and Uzebba (a, b, c, d, respectively) under plane polarized light $(30 \times)$. $Z=$ Zircon, $R=$ Rutile, $T=$ Toumaline, $G=$ Garnet, $S=$ Staurolite, $K=$ Kyanite, $\mathrm{O}=$ Opaque

Medium sands of moderately well sorted grains, with $50 \%$ each of positively and negatively skewed sediments. $41.7 \%$ both of coarse and strongly coarse skewed and only $16.7 \%$ near symmetry. The sandstone is $50 \%$ mesokurtic, $41.7 \%$ leptokurtic and only $8.3 \%$ platykurtic. Medium sand of poor to moderate sorting, $60 \%$ strongly coarse skewed and $40 \%$ coarse skewed. The sands are $80 \%$ mesokurtic and $20 \%$ leptokurtic.

From the heavy mineral petrographic examination (figure 4), Zircon, Rutile, Tourmaline, Garnet, staurolite and Kyanite together with the Opaque minerals were identified under microscope. The heavy minerals across the study locations are approximately equal in proportions, with the average weight percent of the heavy minerals at Fugar, Fugar II, Ayowuiri, Auchi and Uzebba been 19.97\%, 21.27\%, 18.78\%, $20.88 \%$ and $18.80 \%$ respectively. Implying in terms of heavy minerals abundances, it is most abundance in Fugar II and least in ayogwuiri and Uzebba (been approximately equal weight percent) and in descending order of abundances we have Sandstone at Fugar II, Auchi, Fugar, Uzebba and Ayogwuiri respectively, from table 5. At Fugar I, from table 1, above the sandstone is medium to coarse sand with a graphic mean of $1.0 \phi$ with moderately sorted grains from average inclusive graphic mean of $0.9 \phi$. The (0.263 and 2.041) $\phi$ values for skewness and kurtosis indicate sands that are fine skewed and very leptokurtic. At Fugar II, the Sandstone is medium grained with average graphic mean of $1.35 \mathrm{phi}$. The average of $(0.65,0.055$ and 1.155$) \phi$ values for inclusive graphic mean, skeweness and kurtosis respectively gives sands that are moderately well sorted, near symmetrical and leptokurtic (Table 2). For the Sandstone in Ayogwuiri area, the sands are coarse sands of moderate sorting, from average values of $(0.95$ and 1.0) $\phi$ for graphic mean and inclusive graphic mean (Table 3) Likewise, the average values of (0.097 and 1.082) $\phi$ for skewness and kurtosis reveal that the grain is near symmetry and mesokurtic.

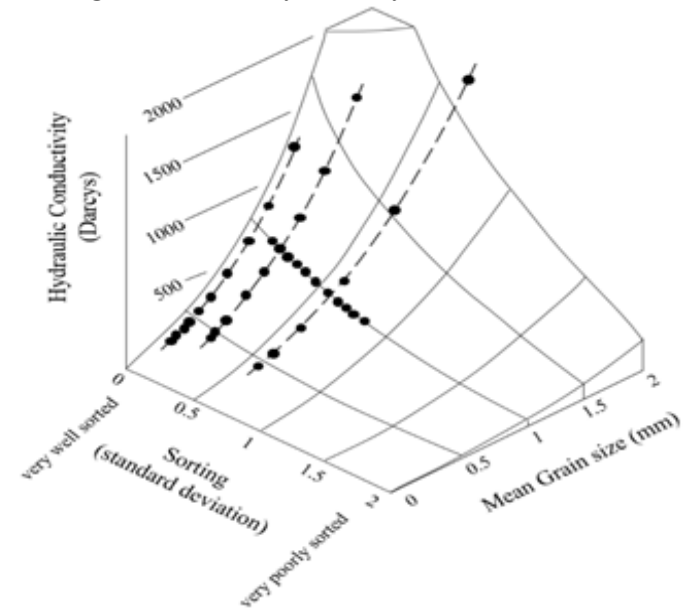

Fig 4. Relationship among hydraulic conductivity (permeability), grain size, and sorting for sand-sized spherical grains (data from Krumbein and Monk, 1942; modified from Allen and Allen, 1990). 


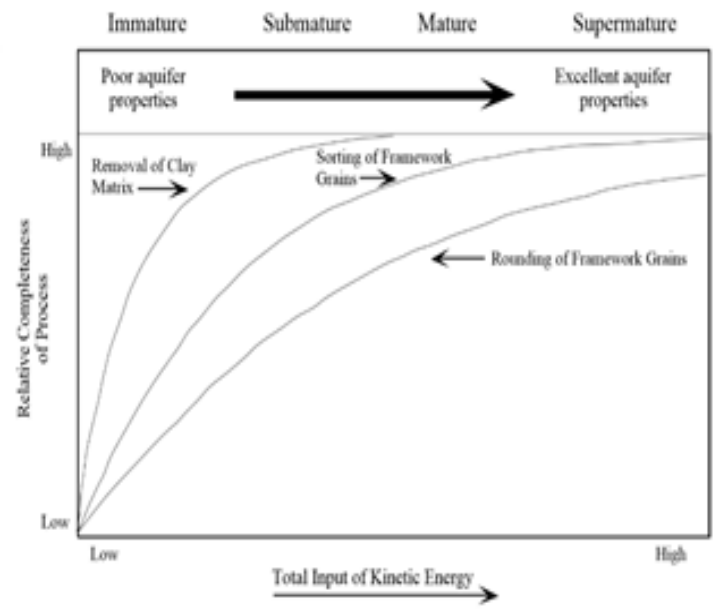

Fig 5. General relationships between textural maturity, sorting, relative amount of clay matrix, aquifer qualities, and the energy in the depositional environment.

The Sandstone at Uzebba (Table 4), the average graphic mean of $2.0 \phi$, with an inclusive graphic mean of $0.9 \phi$, both indicates medium sand of moderately sorting. (0.04 and 1.335) $\phi$ gives sandstone that are near symmetry and leptokurtic. Sandstone located at Auchi (Table 4) is medium sands with moderately sorted grain of (1.75\& 0.9) $\phi$ respectively. The grains are near symmetrical and ranges from mesokurtic to leptokurtic having $(0.0725$ and 1.105$) \phi$. In a related study (Ilevbare and Omodolor, 2020) reported the paleoenvironment of deposition of the Ajali sandstone as Fluviatile. The depositional setting and environmental conditions that establish the initial porosity and permeability relationships of basin-filling sediments range from the micrometer to the kilometer scale. On the scale of depositional environments, the geometry of sand bodies determines the extent and degree of compartmentalization of an aquifer. For example, sand and sandstone bodies have pod to ribbon-like geometries that can be isolated within mud-rich aquitards in meandering fluvial systems. In contrast, the sand and sandstone bodies deposited in a fluvial system have sheet-like geometries that may, or may not, be isolated by mud-rich aquitards. Due to the differences in the extent of aquifer compartmentalization, Sandstone deposited in fluvial environment normally has better hydraulic conductivity than do meandering stream deposits (McBride, 1989).

The differences in the values for kurtosis reflect the flow characteristics of the deposition medium. (Baruah et al., 1997; Ray et al., 2006). The dominance of the mesokurtic and leptokurtic nature of sediments reflects compositionally and mineralogically mature sand. From the heavy mineral result, ZTR index of $67.96 \%$ which according to the maturity classification scheme of Manger and Maurer, 1992, is sub- mature. The mineralogical maturity index (MMI), of 17.4 which is mature (Ilevbare and Imasuen, 2020), and the mesokurtic and leptokurtic nature of sediments which again reflects compositionally and mineralogically mature sands. These sub-mature to mature sandstone indicates a groundwater with excellent aquifer properties, (Blatt, 1992) elucidated by figure 5 .

Furthermore, a look at the sedimentological characteristics for the Ajali sandstone exposed at Fugar and environs, reveals a coarsening upward sequence (increasing grain sizes) with a progressive increase in sorting. Krumbein and Monk, 1942; Allen and Allen, 1990, in a study where they showed the relationship among Hydraulic conductivity, sorting and grain sizes (figure 4), demonstrated that hydraulic conductivity increases with increasing grain sizes and sorting, this again is consistent with the result of this study and gives an excellent aquifer characteristics for the groundwater within the study area.

Conclusion: Based on the grain characteristics and heavy mineral assemblages of Ajali Sandstone, Anambra Basin, these conclusions were arrived at the increasing values of grain sizes and sorting indicate an increased hydraulic conductivity, while ZTR index and Kurtosis of the grains gives an aquifer with excellent properties. The sandstone bodies were deposited in a fluvial palaeo-environment of sheetlike aquifer geometry, hence better hydraulic conductivity and a resulting good aquifer characteristics, hence availability of drinking water for residents within the locality.

\section{REFERENCES}

Allen, PA; Allen, JR; (1990). Basin analysis, principles and applications: Blackwell Science, Oxford, $451 \mathrm{p}$.

Baruah, J; Kotoky, P; Samma, J; (1997). Textural and geochemical study on river sediments: a case study on the Jhanji River, Assam. J. Indian Assoc. Sediment. 16: 195-206.

Blatt,H; (1992). Sedimentary Petrology: Freeman, San Francisco, 514 p.

Hiatt, EE; Kyser, K; (2014). Links between Depositional and diagenetic processes in Basin analysis: Porosity and Permeability Evolution in Sedimentary Rocks. Book chapter: Department of Geological Sciences and Geological Engineering Queen's University Kingston, Ontario, K7L 3N6 Canada. 
Hogue, M; Ezepue, MC; (1977). Petrology and paleogeography of Ajali Sandstone. J. Min. Geol., 14(1): 16-22.

Krumbein, WC; and Monk, GD; (1942), Permeability as a function of the size parameters of unconsolidated sands: Am. Institute Mineral. Metallu. Engineer. Tech. Pub. 1492. 1-11.

Ladipo, KO; (1986). Tidal shelf depositional model for the Ajali Sandstone, Anambra Basin, Southern Nigeria. J. Afr. Earth Sci., 5(2): 177-185.

McBride, EF; (1987). Quartz cement in sandstones: a review, Earth-Science Reviews: 26, 69-112.

Marshall, B; (1967). The present status of Zircon. Sedimentology. 9 .119-136.

Mange, MA; Maurer, FW; (1992). Heavy minerals in colour. Chapman \& Hall, London.

Ramasamy, P; Karikalan R; (2010). Distribution and percentage of heavy minerals in coastal geomorphologial landforms in Palk Strait, Southeast coast of India middle-east. J. Sci. Res. 5(1): 49-53.
Ray, AK; Tripathy, SC; Patra, S; Samma, VV; (2006). Assessment of Godquari estuarine mangrove ecosystem through trace metal studies. Environ. Int. 32: 219-223.

Reyment, RA; (1965). Aspects of the Geology of Nigeria. Univ. Ibadan Press, Nigeria. 145pp.

Simpson, A., (1954). The Nigerian coal fields and the geology of part of Onitsha, Owerri and Benue provinces. Geol. Surv. Niger. Bull., 24: 85.

Ilevbare, M; and Omodolor, HE; (2020). Ancient Deposition Environment, Mechanism of Deposition and Textural attributes of Ajali Formation, Western Flank of the Anambra Basin, Nigeria, Elservier, Case Studies in Chem. Environ. Engineer. 1: 1-23.

Ilevbare, M; and Imasuen OI; (2020). Sedimentology and Maturity of Ajali Formation Anambra Basin, Nigeria. Ife J. Sci. 22(1): 123-136. 